\title{
The growth response to androgen receptor signaling in ERo-negative human breast cells is dependent on p21 and mediated by MAPK activation
}

Joseph P Garay ${ }^{1}$, Bedri Karakas ${ }^{1}$, Abde M Abukhdeir ${ }^{1}$, David P Cosgrove ${ }^{1}$, John P Gustin ${ }^{1,2}$, Michaela J Higgins ${ }^{1}$, Hiroyuki Konishi', Yuko Konishi ${ }^{1}$, Josh Lauring ${ }^{1}$, Morassa Mohseni ${ }^{1}$, Grace M Wang ${ }^{1}$, Danijela Jelovac', Ashani Weeraratna ${ }^{3}$, Cheryl A Sherman Baust ${ }^{3}$, Patrice J Morin ${ }^{3}$, Antoun Toubaji', Alan Meeker ${ }^{1}$, Angelo M De Marzo ${ }^{1}$, Gloria Lewis ${ }^{1}$, Andrea Subhawong ${ }^{1}$, Pedram Argani ${ }^{1}$ and Ben H Park ${ }^{1,2^{*}}$

\begin{abstract}
Introduction: Although a high frequency of androgen receptor (AR) expression in human breast cancers has been described, exploiting this knowledge for therapy has been challenging. This is in part because androgens can either inhibit or stimulate cell proliferation in pre-clinical models of breast cancer. In addition, many breast cancers co-express other steroid hormone receptors that can affect AR signaling, further obfuscating the effects of androgens on breast cancer cells.
\end{abstract}

Methods: To create better-defined models of AR signaling in human breast epithelial cells, we took estrogen receptor (ER)- $\alpha$-negative and progesterone receptor (PR)-negative human breast epithelial cell lines, both cancerous and non-cancerous, and engineered them to express AR, thus allowing the unambiguous study of AR signaling. We cloned a full-length CDNA of human AR, and expressed this transgene in MCF-10A non-tumorigenic human breast epithelial cells and MDA-MB-231 human breast-cancer cells. We characterized the responses to AR ligand binding using various assays, and used isogenic MCF-10A p21 knock-out cell lines expressing AR to demonstrate the requirement for p21 in mediating the proliferative responses to AR signaling in human breast epithelial cells.

Results: We found that hyperactivation of the mitogen-activated protein kinase (MAPK) pathway from both AR and epidermal growth factor receptor (EGFR) signaling resulted in a growth-inhibitory response, whereas MAPK signaling from either AR or EGFR activation resulted in cellular proliferation. Additionally, p21 gene knock-out studies confirmed that AR signaling/activation of the MAPK pathway is dependent on p21.

Conclusions: These studies present a new model for the analysis of AR signaling in human breast epithelial cells lacking ER $\alpha / P R$ expression, providing an experimental system without the potential confounding effects of ER $\alpha / P R$ crosstalk. Using this system, we provide a mechanistic explanation for previous observations ascribing a dual role for AR signaling in human breast cancer cells. As previous reports have shown that approximately $40 \%$ of breast cancers can lack p21 expression, our data also identify potential new caveats for exploiting AR as a target for breast cancer therapy.

\footnotetext{
* Correspondence: bpark2@jhmi.edu

${ }^{1}$ The Sidney Kimmel Comprehensive Cancer Center, The Johns Hopkins

University School of Medicine, Baltimore, MD, USA

Full list of author information is available at the end of the article
}

(c) 2012 Park et al.; licensee BioMed Central Ltd. This is an open access article distributed under the terms of the Creative Commons 


\section{Introduction}

Breast cancer is a disease in which the pathogenesis can be attributed to hormone exposure, the most notable being estrogens. Successful targeted therapies against estrogen receptor (ER) $\alpha$ have been developed, and this remains an active area of research. Many of these therapies directly target ER $\alpha$ or the ER $\alpha$ signaling pathway, and have been shown to be highly efficacious in treating ER $\alpha$-positive breast cancers [1]. However, a significant subset of breast cancers cannot be treated by these therapies because they do not express ER $\alpha$ or its surrogate predictive marker of response, the progesterone receptor (PR), and/or these cancers commonly show resistance to drugs that target the ER $\alpha$ pathway.

Androgens are another class of sex hormones, and epidemiologic studies have supported their role in breast biology and carcinogenesis [2-4]. In fact, the androgen receptor (AR) is expressed in the vast majority of breast cancers, with some studies reporting expression of AR in up to $90 \%$ of primary tumors and $75 \%$ of metastatic lesions $[5,6]$, although more contemporary studies suggest that the frequency of AR expression varies depending on the subtype of breast cancer (for example, ER $\alpha$-positive (luminal) versus triple-negative and basal breast cancers), and other clinical and pathologic parameters [7-9]. In addition, AR expression may also affect outcomes in given subsets of breast cancer. For example, in luminal breast cancers expressing AR, the AR expression is associated with better prognosis [10-12]. Of potential clinical relevance, past studies support the notion that AR agonists may have beneficial effects in treating luminal AR-positive disease [13,14]. Approximately $10 \%$ to $20 \%$ of triple-negative breast cancers are known to express AR [15], and of particular interest is the group termed 'molecular apocrine breast cancer'. This subset of tumors has been shown to be transcriptionally regulated by AR with a luminal gene-expression profile $[16,17]$, and both in vitro and in vivo studies using antiandrogen therapies have shown promising results $[16,18,19]$. Additionally, approximately $20 \%$ of HER2-positive, ER $\alpha$-negative breast cancers have also been shown to express AR $[7,8,20]$. Thus, targeting AR may offer a potent form of hormone therapy for this group of patients, yet despite this, therapies targeting AR for breast cancer are currently not in widespread use. There are numerous reasons for this, including side-effects of masculinization and organ toxicities seen with androgen use [21]. In addition, one of the most problematic issues with androgen use for breast cancer therapy is that androgens can yield either a growth-inhibitory or cell-proliferative effect in pre-clinical models, depending on the breast cancer cell lines being studied, regardless of their ER $\alpha$ status [22]. Moreover, separate groups have described disparate results when examining the response of the same breast cancer cell line to a given AR ligand. This is probably due to cellular changes that can occur in continuous culture, owing to the inherent genetic instability of breast cancer cell lines [23]. However, there are several reasons why AR remains a potential target for breast cancer therapy. First, as mentioned above, a significant percentage of breast cancers (10\% to $20 \%$ ) are AR-positive/ER $\alpha$-negative, thus providing an opportunity for hormone therapies targeting AR in this group of patients. Second, the historical success of targeting AR for prostate cancer provides a proof of principle for its use as a target in cancer therapy. Third, approximately $40 \%$ to $50 \%$ of ER $\alpha$-positive breast cancers treated with conventional hormone therapies such as tamoxifen or aromatase inhibitors (AIs) will recur with drug-resistant disease, and AR-directed therapies may still be efficacious in this patient population. Interestingly, a recent study suggested that AR overexpression may be a mechanism of tamoxifen resistance [24]. Thus, despite the past experience of and caveats about targeting AR for breast cancer, developing novel therapies that target AR could have a significant influence on the treatment of this disease.

As mentioned, laboratory studies assessing the role of AR in breast cancer have been limited and conflicting. In part, this is due to the fact that most AR-positive breast cancer cell lines also express ER $\alpha$ and PR [7,8,25-28]. This can confound analyses of AR receptor signaling for several reasons. When co-expressed, AR and ER $\alpha$ have been shown to physically interact and decrease transcription of response genes [29]. Further complexity occurs due to the promiscuity of a given ligand for multiple nuclear hormone receptors. For example, along with serving as a PR ligand, the synthetic progestin medroxyprogesterone acetate can also bind to AR and function as an AR agonist [30]. Likewise, the ER $\alpha$ antagonist fulvestrant has been shown to downregulate AR expression, and therefore attenuate response to AR ligand [31]. Understanding AR signaling in models of human breast cells that express AR exclusively would help to elucidate the role of AR in breast cancer and further the development of targeted therapies, particularly in the setting of ER $\alpha$-negative disease. However, there are few breast cancer cell lines that express AR as the sole sex-hormone receptor, and those that do exist often harbor numerous genetic anomalies that could potentially alter AR signaling. For example, the cell line MDA-MD-453 is AR-positive/ER $\alpha$-negative, but this cell line also has a homozygous deletion of TP53, a homozygous PTEN missense mutation, HER2 amplification, and an oncogenic mutation in PIK3CA (Sanger Catalogue of Somatic Mutations in Cancer (COSMIC) database; http:// www.sanger.ac.uk/genetics/CGP/cosmic) [32,33].

To circumvent this issue, we expressed AR in a genetically well-defined, non-tumorigenic, human breast epithelial cell line, MCF-10A. This cell line is spontaneously 
immortalized as a result of homozygous loss of the chromosomal region 9p, but is genetically stable [23]. Further, we previously used this cell line to generate stable ER $\alpha$ expressing clones with physiologic responses to estrogen including growth stimulation by estrogen, which is blocked by tamoxifen and the induction of luminal-type genes by estrogen stimulation [34].

In this paper, we report and characterize a similar model to study AR signaling in human breast epithelial cell lines. We found that in MCF-10A cells expressing AR, co-stimulation of EGFR signaling with AR ligand binding led to a growth-inhibitory effect due to hyperactivation of the mitogen-activated protein kinase (MAPK) pathway. However, MAPK activation with either AR ligand binding or EGFR activation resulted in cellular proliferation. Moreover, using a genetics-based approach, we found that the effects of AR signaling in MCF-10A cells were mediated through the cyclin-dependent kinase (CDK) inhibitor p21. These data further elucidate the mechanisms that affect AR signaling, and therefore may aid in the development of drugs targeting AR for breast cancer therapy.

\section{Materials and methods}

\section{Ethics approval}

This was a pre-clinical study not involving human subjects, and therefore did not require ethical review by an institutional review board.

\section{Plasmids and cell culture}

AR cDNA was cloned into a modified version of the pIRESneo3 vector (Clontech, Mountain View, CA, USA), a bicistronic vector with an internal ribosomal entry site (IRES) and the gene encoding neomycin resistance (see Additional file 1 Table 1 for primers used). All cells [there seems to be some text deleted here from our manuscript. Should be along "All cells were purchased from ATCC"] (American Type Culture Collection (ATCC), Manassas, VA, USA) and grown at $37^{\circ} \mathrm{C}$ with $5 \% \mathrm{CO}_{2}$. MCF-7, MDA-MB-231, and MDA-MB-453 cells were grown in DMEM (Invitrogen Corp., Carlsbad, CA, USA) supplemented with 5\% FBS (Hyclone Laboratories Inc., Logan, UT, USA), $100 \mathrm{U} / \mathrm{ml}$ penicillin and $100 \mu \mathrm{g} / \mathrm{ml}$ streptomycin (both Invitrogen Corp.). Clones of MDA-MB-231 stably overexpressing AR cDNA were isolated and propagated in DMEM:F12 (1:1) without phenol red (Invitrogen Corp.), supplemented with $5 \%$ charcoal dextran-treated FBS (Hyclone Laboratories Inc.), $100 \mathrm{U} / \mathrm{ml}$ penicillin, $100 \mu \mathrm{g} / \mathrm{ml}$ streptomycin, and $500 \mu \mathrm{g} / \mathrm{ml} \mathrm{G} 418$ (all Invitrogen Corp.). The non-transformed human breast epithelial cell line MCF-10A [35] was grown in DMEM:F12 (1:1) supplemented with $5 \%$ horse serum (GIbco, Carlsbad, CA, USA), $20 \mathrm{ng} / \mathrm{ml}$ epidermal growth factor (EGF), $10 \mu \mathrm{g} / \mathrm{ml}$ insulin, $0.5 \mu \mathrm{g} / \mathrm{ml}$ hydrocortisone, and $0.1 \mu \mathrm{g} / \mathrm{ml}$ cholera toxin (all Sigma-Aldrich, St. Louis, MO, USA) unless otherwise noted. All MCF-10A derivatives were selected on medium containing $120 \mu \mathrm{g} / \mathrm{ml} \mathrm{G418.} \mathrm{Cells} \mathrm{designated}$ as Androgen Receptor In Breast Epithelium (ARIBE) cells were isolated and propagated in DMEM:F12 (1:1) without phenol red, supplemented with $5 \%$ charcoal dextran-treated FBS (Hyclone Laboratories Inc.). Two representative clones, ARIBE-1 and ARIBE-2, were used for all subsequent experiments.

Generation of the MCF-10A p21/- cell line has been described previously [36]. Because these cells utilize both neomycin and hygromycin for disruption of the $p 21$ gene, AR cDNA was subcloned into pIRESpuro2 (Clontech). Cells were selected on medium containing $0.4 \mu \mathrm{g} / \mathrm{ml}$ puromycin (Sigma), and propagated in the same medium as used for the ARIBE cells.

\section{Cell-proliferation assays}

For crystal violet staining, ARIBE and control cells were seeded in $25 \mathrm{~cm}^{2}$ tissue-culture flasks at $10^{5}$ cells/flask. The medium was changed 24 hours later and appropriate drug or vehicle added. All drugs and vehicle controls constituted $0.1 \%$ of the final volume in the flasks. The synthetic androgen R1881 (Perkin Elmer LAS, Boston, MA, USA) was diluted in ethanol (EtOH) and used at a concentration of $1 \mathrm{nmol} / \mathrm{l}$. The androgen antagonist bicalutamide (Toronto Research Chemicals, Ontario, Canada) was diluted in methanol and used at a concentration of 10 $\mathrm{nmol} / \mathrm{l}$. Control cells were treated with EtOH only. After 3 days, or when the cells in the control flasks were at $90 \%$ to 95\% confluency, all flasks were stained with crystal violet (Sigma) diluted in formalin to a concentration of $2 \mathrm{mg} / \mathrm{ml}$.

All other growth assays were performed in 12-well tissue-culture plates. Cell counting was performed on a viability analyzer (Vi-Cell; Beckman Coulter, Fullerton, CA, USA), and all counts were performed in triplicate and repeated at least three times. For ARIBE cell assays, exponentially growing ARIBE and control cells were washed with Hank's balanced salt solution (HBSS; Invitrogen Corp.) three times, and seeded in DMEM:F12 medium without phenol red, using $2 \%$ charcoal dextran-treated serum, $10 \mu \mathrm{g} / \mathrm{ml}$ insulin, $0.5 \mu \mathrm{g} / \mathrm{ml}$ hydrocortisone, and $0.1 \mu \mathrm{g} / \mathrm{ml}$ cholera toxin, either without EGF or with $20 \mathrm{ng} / \mathrm{ml} \mathrm{EGF}$, as indicated. Cells were seeded at a density of $1.5 \times 10^{4}$ cells/well for experiments without EGF and at $5 \times 10^{3}$ cells/well for experiments using $20 \mathrm{ng} / \mathrm{ml}$ EGF. Medium was changed 24 hours later (day 0 ), and the drug or vehicle was added to the appropriate wells. All drugs and vehicle controls constituted $0.1 \%$ of the final volume in the wells. Medium was changed every other day until cells were counted. Cells were counted on days 0 , 4 , and 8 for experiments without EGF, and days 0 , 2 , and 4 for experiments using $20 \mathrm{ng} / \mathrm{ml} \mathrm{EGF}$.

MDA-MD-231 cell assays were performed similarly. Cells were seeded in DMEM:F12 (1:1) without phenol 
red, supplemented with $2 \%$ charcoal dextran-treated serum at a density of $10^{4}$ cells/well. Cells were counted on day 4. The MAPK kinase (MEK) inhibitor U0126 (Promega Corp., Madison, WI, USA) [37] was diluted in DMSO (Sigma) and used at a concentration of $1 \mu \mathrm{mol} / \mathrm{l}$.

\section{Immunoblotting and quantification}

Whole-cell protein extracts prepared in Laemmli sample buffer were resolved by SDS-PAGE using $4 \%$ to $12 \%$ polyacrylamide gels (NuPage; Invitrogen Corp.), transferred to PVDF membranes (Invitrolon; Invitrogen Corp.), and probed with primary and horseradish peroxidase-conjugated secondary antibodies. Primary antibodies were rabbit polyclonal anti-p44/p42 MAPK (ERK) (9102; Cell Signaling Technology, Danvers, MA, USA), mouse monoclonal anti-phospho-p44/p42 MAPK (ERK) (Thr-202/Tyr-204) (9106; Cell Signaling Technology), mouse monoclonal anti-AR (sc-7305; Santa Cruz Biotechnology, Santa Cruz, CA, USA), mouse monoclonal anti-p21/WAF (\#OP64; Calbiochem, Gibbstown, NJ, USA), rabbit polyclonal anti-glucocorticoid receptor (7437; Cell Signaling Technology) and mouse monoclonal anti-GAPDH (6C5) (ab\#8245; Abcam, Cambridge, MA, USA). Proteins were visualized with chemiluminescence (Western Lightning Plus; Perkin Elmer). All blots were quantified using ImageJ software [38] and were normalized to their respective GAPDH loading control.

\section{Cell cycle analysis}

Cells were seeded in six-well plates, and drug or vehicle was added the following day. Cells were then harvested and analyzed by fluorescence-activated cell sorting (FACS) analysis at 6 hours or 36 hours after drug addition. Cells were fixed in PBS with $3 \%$ formaldehyde and $0.4 \% \mathrm{NP}-40$, containing $2 \mu \mathrm{g} / \mathrm{ml}$ dye (Hoechst 33258; Invitrogen Corp.). DNA content was measured with a flow cytometer (BD LSR; BD Biosciences, San Jose, CA, USA), and percentages of $\mathrm{G} 1 / \mathrm{G} 0, \mathrm{~S}$, and $\mathrm{G} 2 / \mathrm{M}$ phase cells were determined using Modfit LT software (Verity Software House, Topsham, ME, USA).

\section{Luciferase assays}

All luciferase experiments were performed in duplicate and repeated at least twice. Cells were seeded in 96-well plates (Microtest Optilux, BD Falcon, Franklin Lakes, NJ, USA) at $15 \%$ confluency in the medium described above for the cell-proliferation assays with $20 \mathrm{ng} / \mathrm{ml}$ EGF. At 24 hours after seeding, cells were transfected and concurrently treated with either $1 \mathrm{nmol} / \mathrm{l} \mathrm{R} 1881$ or vehicle control. The transfection mixture per well contained $12.5 \mu \mathrm{L}$ reduced serum medium (Opti-MEM; Invitrogen Corp.), $0.5 \mu \mathrm{L}$ transfection reagent (Fugene 6; Roche USA, Nutley, NJ, USA), and $100 \mathrm{ng}$ total plasmid. The reporter plasmids consisted of either three copies of a wild-type consensus binding site for $A R$, or three copies of a mutated binding site of AR conjugated to a firefly luciferase reporter. The consensus binding sites used in the construction of the reporters were gtacattGtGttct for AR, and gtaAattGtAttTt for the mutated AR consensus binding sites. Additionally, each well was co-transfected with a Renilla luciferase plasmid to serve as control for transfection efficiency.

At 48 hours after drug treatment and transfection, luciferase activity was assayed using a commercial luciferase assay system (Dual-Glo; Promega Corp.) following the manufacturer's protocol. Briefly, cells were lysed with $150 \mu \mathrm{L}$ of a 1:1 mixture of luciferase (Dual-Glo) and medium (Opti-MEM), and incubated at room temperature for 15 minutes. Firefly luciferase activity was measured by a luminometer (TopCount NXT; Perkin Elmer) for $2 \mathrm{sec}-$ onds per well, then quenched with $75 \mu \mathrm{L}$ of the provided reagent (Stop \& Glo; Promega Corp.). Fifteen minutes after quenching firefly luciferase activity, Renilla luciferase activity was measured on the luminometer for 2 seconds per well. All firefly luciferase measurements were normalized to Renilla luciferase measurements. AR activity was expressed as the ratio of the luciferase activity in cells transfected with consensus binding site plasmids divided by the luciferase activity in cells transfected with mutated binding site plasmids.

\section{CDNA synthesis and quantitative real-time reverse transcriptase PCR}

Total RNA was extracted from cells (RNeasy Mini Kit; Qiagen Inc., Valencia, CA, USA) according to the manufacturer's instructions, with on-column DNAse I digestion, then complementary DNA was synthesized (First Strand cDNA Synthesis Kit; GE Amersham, Pittsburgh, PA, USA). Using cDNA as template and SYBR Green (Invitrogen Corp.) to detect DNA products, expression of insulinlike growth factor (IGFR)-1 was assayed using a two-color real-time detection system (MyiQ; (BioRad, Hercules, CA, USA). Reactions were performed in triplicate, and repeated at least twice. Transcript levels were normalized to TATA binding protein $(T B P)$ levels in the same samples in each experiment. FKBP5, NSDHL and IGFR-1 gene expression was reported as a ratio of the expression in cells treated with drug divided by the expression in cells treated with vehicle. Quantitative real-time reverse transcription PCR (qPCR) was performed (for primers, see Additional file 1 Table 1).

\section{Fluorescent in situ hybridization analyses}

For fluorescent in situ hybridization (FISH) analysis, tissue pre-treatment was first performed using paraffin wax-embedded tissue sections 4 to $5 \mu \mathrm{m}$ thick that had been mounted on charged microscope slides, which were dewaxed, rehydrated through a decreasing graded 
ethanol series, and treated using a commercial tissue protease kit (Pre-treatment Kit III; Abbott Molecular Inc.,/Vysis Inc., Downers Grove, IL, USA) according to the manufacturer's directions. After halting protease activity with the provided stop solution, slides were washed, then dehydrated through an increasing graded ethanol series and taken to hybridization. Fluorescently labeled hybridization probes for the $\mathrm{X}$ centromere (CEP X Alpha SpectrumGreen; Abbott Molecular/Vysis) and the AR locus at Xq12 (AR gene probe SpectrumOrange; Abbott Molecular/Vysis) were diluted in hybridization buffer (50\% formamide, $2 \times$ saline sodium citrate (SSC), $10 \%$ Dextran Sulfate), mounted on slides, covered with coverslips, and denatured at $95^{\circ} \mathrm{C}$ for 5 minutes. Hybridization was conducted overnight at $37^{\circ} \mathrm{C}$. Slides were then washed for 4 minutes at room temperature in post-hybridization wash buffer $(2 \times \mathrm{SSC}, 0.3 \% \mathrm{NP}-40)$, followed by a second wash with $\mathrm{SSC}$ at $75^{\circ} \mathrm{C}$ for $3 \mathrm{~min}$ utes, and then a third wash with water at room temperature for 4 minutes. Slides were then counterstained with DAPI (1:10,000 dilution in water from $5 \mathrm{mg} / \mathrm{ml}$ stock; Sigma Chemicals) for 5 minutes at room temperature. Coverslips were mounted using anti-fade mounting medium (Prolong Gold[ Invitrogen Corp./ Molecular Probes), and the slides were sent for analysis. Slides were imaged with an epifluorescence microscope (50i; Nikon, Tokyo, Japan) equipped with an illuminator (X-Cite series 120; EXFO Photonics Solutions Inc., Ontario, CA, USA) and a $10 \times / 1.4$ NA oil immersion lens (Neofluar; Carl Zeiss Inc., Thornwood, NY, USA). Fluorescence excitation/emission filters were as follows: SpectrumOrange excitation, $546 \mathrm{~nm} / 10 \mathrm{~nm}$ BP; emission, $578 \mathrm{~nm}$ LP (Carl Zeiss Inc.); DAPI excitation, 330 $\mathrm{nm}$; emission, $400 \mathrm{~nm}$ via an XF02 fluorescence set (Omega Optical, Brattleboro, VT, USA); SpectrumGreen excitation, $475 \mathrm{~nm}$; emission, $535 \mathrm{~nm}$ via a combination of 475RDF40 and 535RDF45 filters (Omega Optical). Grayscale images were captured for presentation using NIS-Elements software (Nikon) and an attached digital camera (CoolsnapEZ; Photometrics, Tucson, AZ, USA), pseudo-colored, and merged.

\section{Tissue Microarrays}

A previously described (@) breast cancer tissue microarray was used for FISH analysis. Two blocks were employed consisting of 30 and 35 (total $=65$ ) samples of primary invasive ductal carcinomas. Tissue microarrays were prepared for FISH analysis as described above.

\section{Enzyme linked immunosorbent assays (ELISA)}

For PSA ELISAs, growth assays were performed as above and supernatants harvested at the end of Day 4. Supernatants were then subjected to ELISAs using the Quantikine human Kallekrein3/PSA Immunoassay kit (R \& D systems, Minneapolis, MN) as per the manufacturer's protocol.

\section{Statistical analysis}

All statistical analyses were performed using GraphPad InStat software (La Jolla, CA, USA). $P<0.05$ was considered significant.

\section{Results}

\section{Androgen receptor is not amplified in human breast cancers}

As mentioned above, many previous studies have identified AR expression in human breast cancers. However, levels of AR expression (that is, AR overexpression), have been infrequently reported due to difficulty with quantification by immunohistochemistry staining. However, recent studies suggest that overexpression of AR in breast cancer does occur, and is associated with overexpression of ER $\alpha$ and in breast cancers with PIK3CA mutations in the kinase domain $[24,39]$. In addition, AR overexpression and AR gene amplification have been reported in prostate cancers [40]. Although ER $\alpha$ gene amplification in breast cancers is controversial [41], we performed FISH analysis on tissue microarrays (TMAs) with known AR-positive breast cancers using a gene probe for AR and a centromeric chromosome $\mathrm{X}$ probe to query for AR gene amplification. There were approximately two copies of AR for every two copies of chromosome $\mathrm{X}$ in primary breast cancer samples. Although overexpression is difficult to quantify, the complete lack of AR gene amplification strongly suggests that gene amplification is not a common event in human breast cancers. The cell line E006AA has a known AR amplification [42] and was used as a positive control for this assay (see Additional file 1 supplementary Figure 1). Similar to ER $\alpha$, the results confirm that in the high percentage of breast cancers that express AR, gene amplification does not seem to be a major underlying genetic change.

\section{Stable expression of androgen receptor in human breast cells}

To study AR signaling in ER $\alpha$-negative non-tumorigenic human breast epithelial cells, we transfected MCF-10A cells with an AR cDNA using a bicistronic vector with an IRES and the gene encoding neomycin resistance. Multiple clones were isolated and designated as ARIBE cells with two representative clones, ARIBE-1 and ARIBE-2, used for all subsequent experiments. As a control, MCF$10 \mathrm{~A}$ cells were transfected with an 'empty' vector and underwent the same antibiotic selection and single-cell dilution process. Western blot analysis identified high levels of expression of AR in ARIBE-1 and ARIBE-2, which was higher than the expression in MDA-MB-453 


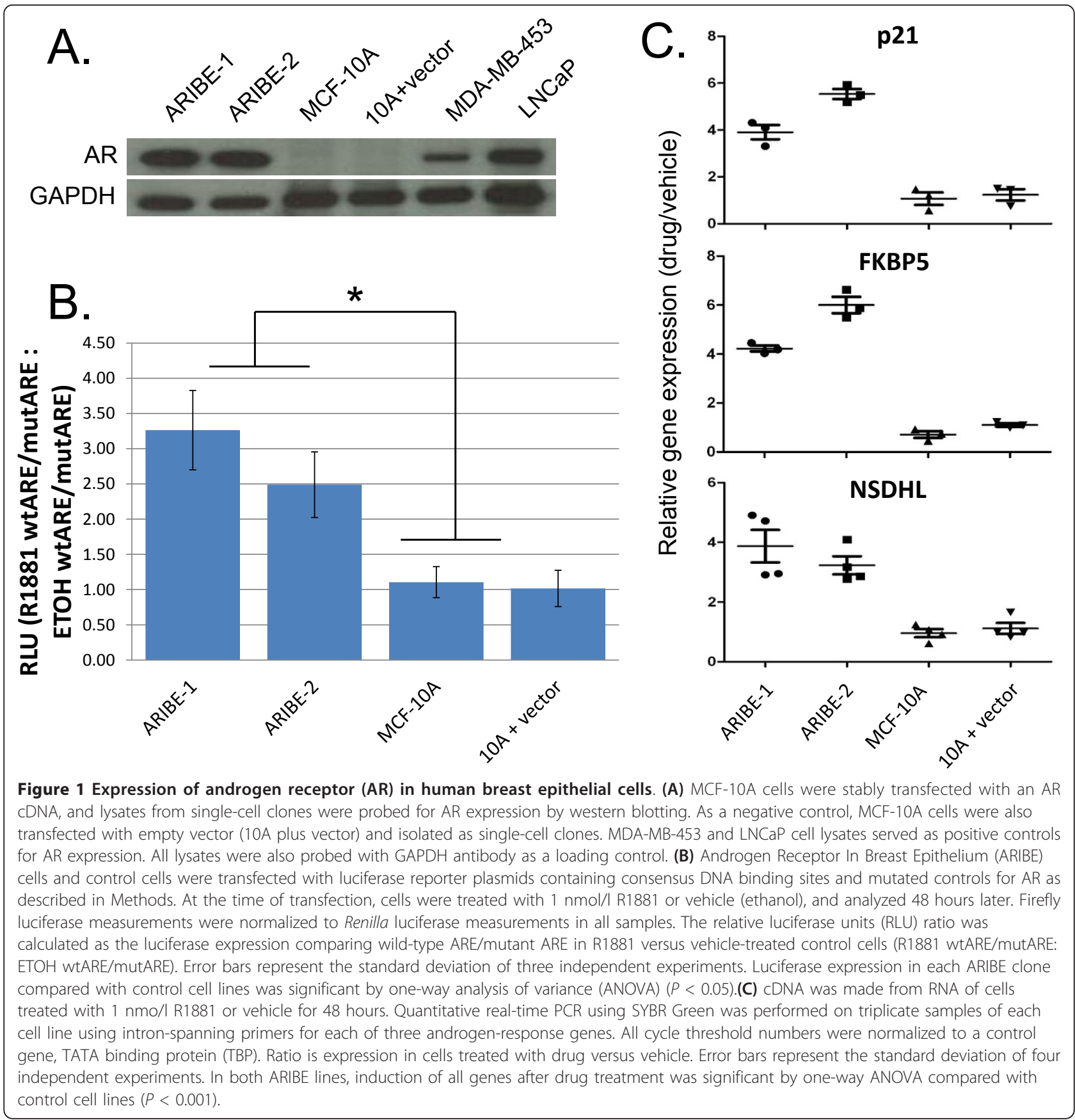

cells, but comparable with levels in the AR-positive prostate cancer cell line LNCaP (Figure 1A; see Additional file 1 supplementary Table 2). As expected, MCF-10A parental cells and the MCF-10A empty vector control had no appreciable AR expression.

We initially characterized the effects of AR ligand binding on ARIBE cells using a luciferase reporter system, and examined changes in AR response genes using qPCR. The luciferase reporter system employs plasmids that contain a firefly luciferase reporter gene driven by either a wild-type consensus binding site for AR (androgenresponse element; ARE) or a mutated ARE that has been shown to have reduced binding affinity for AR. If AR is active, it will drive luciferase expression when transfected with the wild-type plasmid but not with the mutant plasmid. In all experiments, a Renilla luciferase plasmid was co-transfected with the firefly luciferase plasmid as a control for transfection efficiency. We assayed the activity of AR in our ARIBE cell lines and in control cell lines cultured with the synthetic androgen R1881 or vehicle 
control. R1881 is a non-aromatizable synthetic analog of testosterone, and has been shown to saturate AR binding sites in certain breast cancer cell lines at concentrations in the range of 1 to $100 \mathrm{nmol} / \mathrm{l}$ [30]. The relative ratio of luciferase activity of the wild-type ARE to mutant ARE was significantly increased in R1881-stimulated conditions relative to treatment with vehicle only $(\mathrm{EtOH})$ (that is, R1881 wtARE/mutARE: ETOH wtARE/mutARE) in the two ARIBE clones compared with the control cell lines (Figure 1B). To show that AR stimulated by ligand in ARIBE cells also affected gene expression of endogenous AREs, we performed qPCR on known AR response genes. Prostate-specific antigen (PSA) is the prototypical AR response gene, and has been reported to be expressed and secreted by some breast cancer cell lines, although many AR-positive breast cancer cell lines do not produce PSA upon AR ligand binding [43]. Similarly, we did not detect PSA in ARIBE cell cultures either by qPCR of cellular mRNA or by ELISA of cell supernatant, although we could readily detect PSA from the prostate cancer cell line LNCaP upon R1881 stimulation (data not shown). Because of the inability to use PSA as a marker for AR signaling, we examined other known androgen-responsive genes including IGFR-1 [44,45], p21 [46], FKBP5 [47] and NSDHL [48]. qPCR was performed on mRNA derived from ARIBE cells and controls to determine the change in gene expression of these four genes when stimulated with AR ligand. After 24 and 48 hours of AR ligand exposure, there was significantly increased induction of $p 21, F K B P 5$ and NSDHL expression in ARIBE cells compared with MCF-10A or vector control cell lines when stimulated with R1881 (data for 48 hours shown in Figure 1C). IGFR-1 expression was significantly induced at 24 hours (see Additional file 1 supplementary Figure 2) after AR ligand exposure, but was not significantly upregulated at the 48 -hour time point relative to controls.

\section{Proliferative response to androgen receptor ligand in Androgen Receptor In Breast Epithelium cells}

Because the growth response to AR ligands in breast cells can vary depending on the cell line, we next evaluated any proliferative effects of R1881 on ARIBE cells. Treating ARIBE cells with $1 \mathrm{nmol} / \mathrm{l}$ R1881 resulted in significant $(P<0.001)$ growth inhibition (Figure $2 \mathrm{~A}$; see Additional file 1 supplementary Figure $3 \mathrm{~A}$ ). To confirm that this effect was due to signaling through AR, we concurrently treated the cells with the androgen antagonist bicalutamide. When bicalutamide was used in combination with R1881, the inhibitory effect of R1881 was greatly diminished, restoring cell proliferation to levels close to those seen with bicalutamide alone or vehicle control (Figure 2A; see Additional file 1 supplementary Figure 3A). In addition, ARIBE cells showed a dose-dependent inhibitory response to serial dilutions of R1881 (see Additional file 1 supplementary Figure 3B). The observed half-maximal inhibitory concentration (IC50) was approximately $60 \mathrm{pmol} / \mathrm{l}$ which is consistent with that from reports of other cell lines [49-51] implying that our model is accurately recapitulating AR signaling. To determine optimal phenotypic changes as a result of AR signaling, we performed a time-course analysis of ARIBE cells exposed to AR ligand (see Additional file 1 supplementary Figure 4). A marked difference in growth was seen at 48 hours, and the difference between ARIBE cells treated with R1881 versus vehicle continued to increase with prolonged exposure to these culture conditions. Based on these results, a 48-hour exposure to R1881 was used for assessing downstream AR signaling events for subsequent experiments.

Previous studies in our laboratory have shown that manipulation of mitogenic factors can influence the response to nuclear hormone receptor ligands [34]. MCF10A cells provide an ideal system to study these effects because normal propagation requires EGF, and removal of this growth factor results in inactivation of MAPK signaling and a complete arrest of cell cycle in G1[34,35,52]. Interestingly, removal of EGF from cell cultures reversed the effects of R1881, resulting in proliferation rather than growth inhibition of ARIBE cells, which was significant $(P<0.01)$ (Figure $2 \mathrm{~B})$. Without EGF in the culture medium, the doubling time of ARIBE cells treated with R1881 was much longer than the doubling time of MCF-10A or ARIBE cells cultured in medium with EGF and no R1881 (Figure 2A versus Figure 2B). Therefore, the cell-proliferation assay for ARIBE cells cultured in R1881 without EGF was carried out for 8 rather than 4 days. Nonetheless, the effects were obvious and highly reproducible. Moreover, the addition of bicalutamide antagonized the effect of R1881 in ARIBE cells in both EGF-containing and EGFfree conditions, indicating that both growth inhibition and cell proliferation were mediated through AR signaling.

\section{Effects of androgen receptor signaling in Androgen Receptor In Breast Epithelium cells}

To determine whether the growth inhibition induced by R1881 was the result of cell death or cell cycle arrest, we performed FACS analyses on ARIBE cells cultured in the presence of EGF with and without R1881. There was no significant difference between vehicle-treated and drugtreated cells at 6 hours, but at 36 hours, the cells treated with R1881 showed an increase in the G1/G0 cell cycle fraction compared with cells treated with vehicle (see Additional file 1 supplementary Figure 5A). Cells treated with R1881 arrested in G1/G0 but remained viable, as shown by the fact that replacement of the culture medium with medium containing EGF but without R1881 restored a normal cell cycle profile within 48 hours (see Additional file 1 supplementary Figure 5B). 


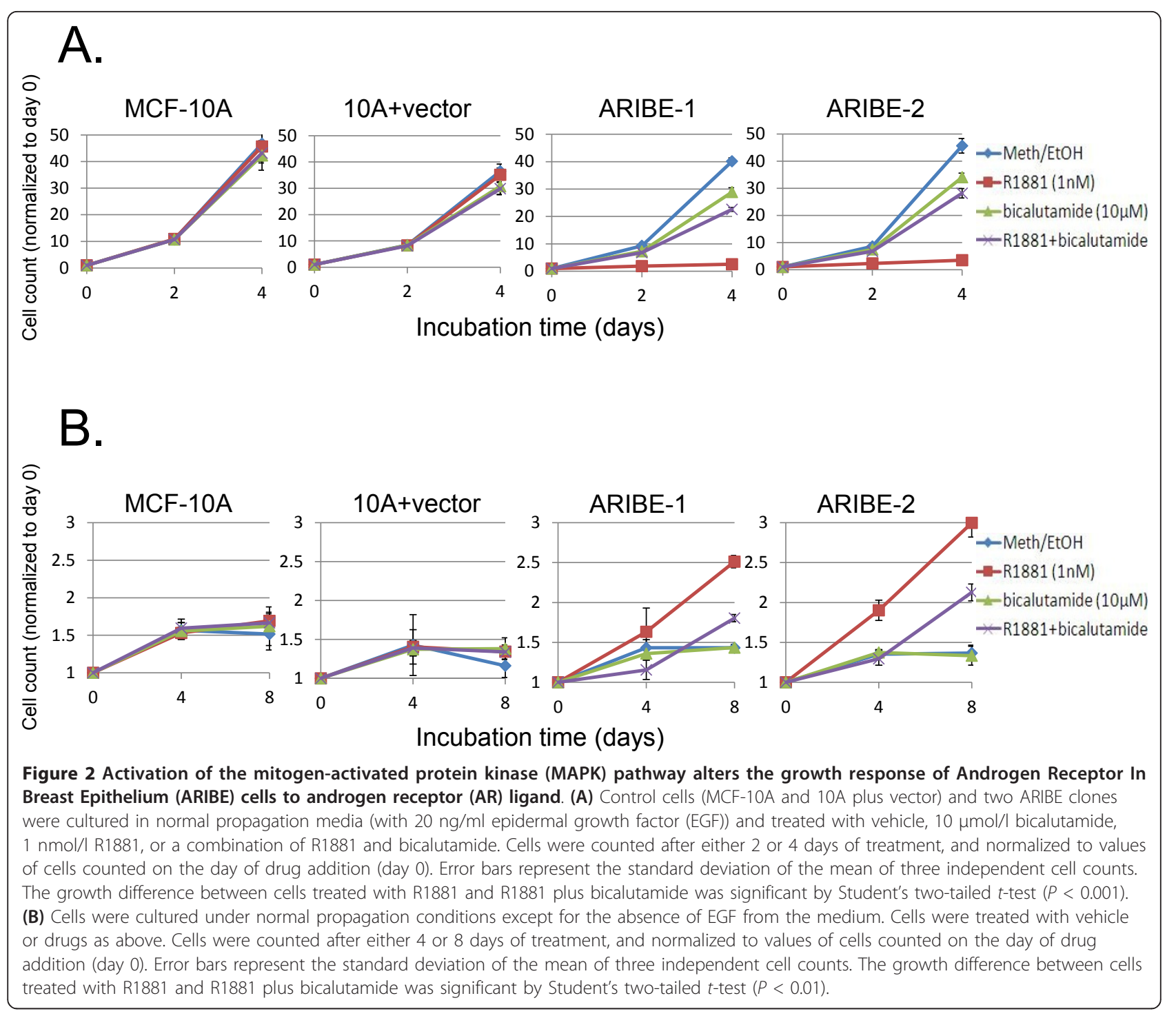

We next determined the signaling pathways that were activated by AR-mediated cell proliferation in ARIBE cells. Previous studies have reported that AR signaling can activate the MAPK pathway via phosphorylation of extracellular signal-regulated kinase (ERK) [53]. We examined phospho-ERK levels in our ARIBE cells under R1881-induced proliferative conditions. Cells were seeded in medium without EGF, and exposed to R1881 or vehicle control for 48 hours, then harvested for cell lysates. As expected, control cell lines had no appreciable increase in phosphorylated ERK levels whereas ARIBE cells had a marked increase in phosphorylated ERK when treated with R1881 (Figure 3, right panel; see Additional file 1 supplementary Table 2). These data are consistent with previous reports that AR signaling can lead to a mitogenic response via MAPK activation, and lend further support to the notion that ARIBE cells demonstrate physiologic AR signaling. Interestingly and seemingly paradoxically, the growth-inhibitory phenotype seen with the full dose $(20 \mathrm{ng} / \mathrm{ml})$ of EGF also showed increased phosphorylation of ERK in ARIBE cells treated with R1881 (Figure 3, left panel; supplementary Table 2) suggesting that the growth-inhibitory response may be due to overactive MAPK signaling (see Discussion).

Collectively, these data suggest that ARIBE cells exposed to R1881 display physiologic AR signaling, based upon cellular growth patterns that are antagonized by bicalutamide, activation of key signal transduction pathways, and the ability to upregulate gene expression via known AREs.

\section{Androgen receptor signaling in breast cancer cells}

To ensure that the results seen with ARIBE cells were due to signaling through AR and were not a unique 


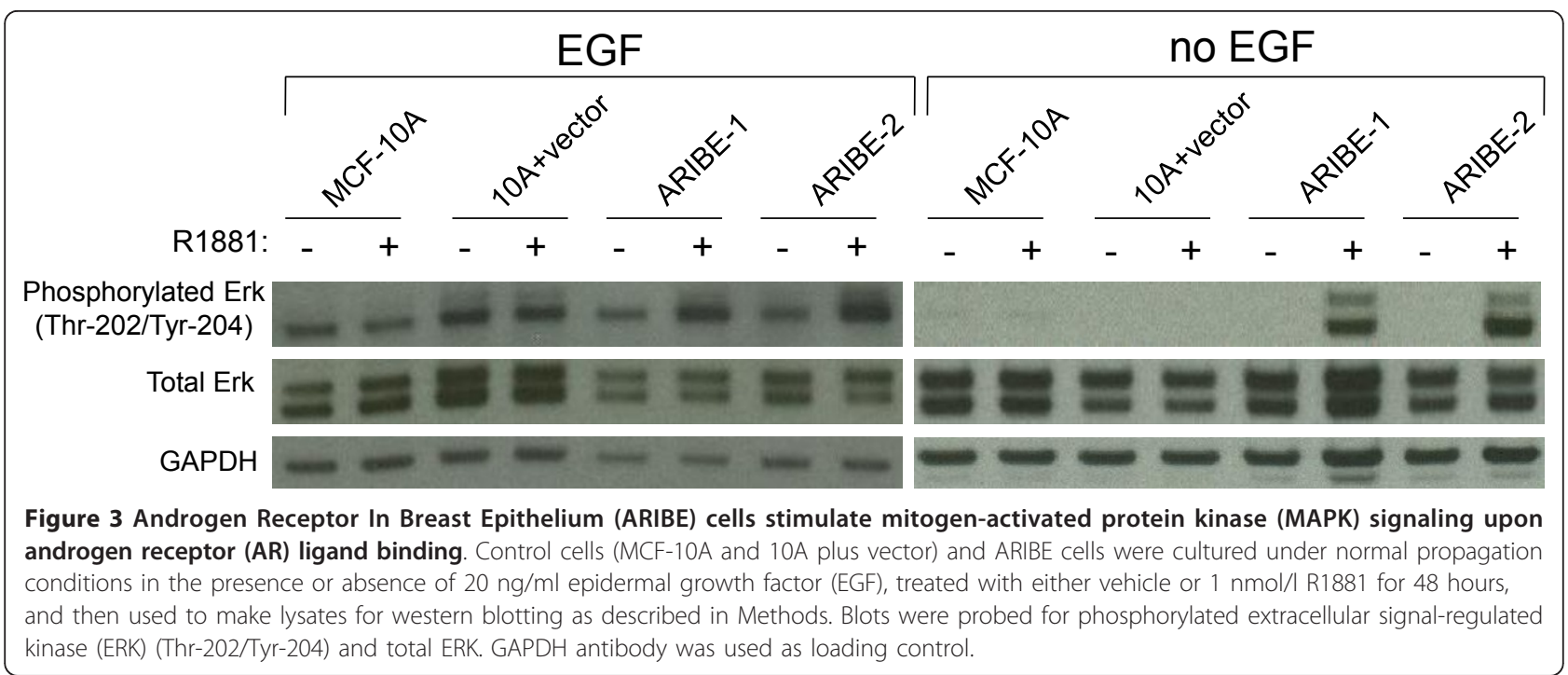

response of MCF-10A cells or artifacts from random transgene insertion, we created a second AR-expressing cell line. We used the MDA-MB-231 cell line because it is also ER $\alpha / \mathrm{PR} / \mathrm{HER} 2$-negative, and has a defined number of mutations in key oncogenes (Sanger COSMIC database). This cell line overexpresses EGFR, which leads to autophosphorylation of EGFR and constitutive activation of the MAPK pathway [54,55]. MDA-MB-231 cells also harbor a KRAS mutation and a BRAF mutation, both of which could further activate the MAPK pathway. However, it has been shown that this cell line is relatively genetically stable compared with other breast cancer cell lines [23]. We subjected he MDAMB-231 cells to the same protocol performed on MCF$10 \mathrm{~A}$ cells, and western blot analysis of the 231 plus AR clones found similar levels of AR expression to those found in MCF-10A cells (Figure 4A; see Additional file 1 supplementary Table 2).

A control cell line was also created by transfecting MDA-MB-231 cells with the empty vector and selecting antibiotic-resistant clones. When stably expressing AR, these cells showed similar responses to R1881 as seen in ARIBE cells; that is, growth inhibition occurred in a dose-dependent manner but with a higher IC50 compared with ARIBE cells, and this effect was blocked by co-culture with bicalutamide (data not shown). A potential caveat to these studies is that R1881 has been shown to bind to the glucocorticoid receptor (GR) [56], and therefore expression of GR was examined in all cell lines. We found that cell lines with AR expression did indeed express GR, but GR expression was also seen in the parental cell lines and in empty vector control cell lines that do not express AR (see Additional file 1 supplementary Figure 6 and Supplementary Table 2). The fact that GR expression was present in all cell lines, in conjunction with the demonstration that the AR antagonist bicalutamide blocked the effects of R1881 only in AR-expressing clones, strongly supports that our model systems accurately reflect physiologic AR signaling.

Because of the aforementioned genetic alterations in the MAPK pathway in MDA-MB-231 cells, no exogenous growth factors are needed for propagation. Therefore, to simulate EGF removal, we used pharmacological inhibitors of the MAPK pathway and then assayed the response to R1881. We used the MEK inhibitor U0126 [37] because this inhibitor would theoretically be active in cells with $R A S$ and $R A F$ mutations, given that MEK is distal to these proteins in the MAPK pathway. R1881 had no effect on empty vector control cells but caused marked growth inhibition in two AR-expressing clones (Figure 4B). Addition of $1 \mu \mathrm{mol} / \mathrm{l}$ U0126 produced significant toxicity in all three cell lines regardless of AR expression, but also produced the expected effect of reversing the response to R1881 in AR-expressing clones $(P<0.005)$. Collectively, these results and the ARIBE cell line data show that AR signaling with concurrent MAPK activation via the EGFR pathway can lead to cell cycle arrest. Additionally, these observations led us to hypothesize that the cells are undergoing a phenomenon similar to oncogene-induced senescence, whereby the hyperstimulation of growth-promoting pathways and/or DNA damage may induce cellular death/arrest or induce senescence [57].

\section{Androgen receptor signaling is mediated by $\mathrm{p} 21$ in breast epithelial cells}

The CDK inhibitor p21 is involved in regulating cell cycle progression, specifically in mediating G1 arrest [58]. We found that under conditions of EGF stimulation, ARIBE cells treated with R1881 underwent arrest in the G1/G0 


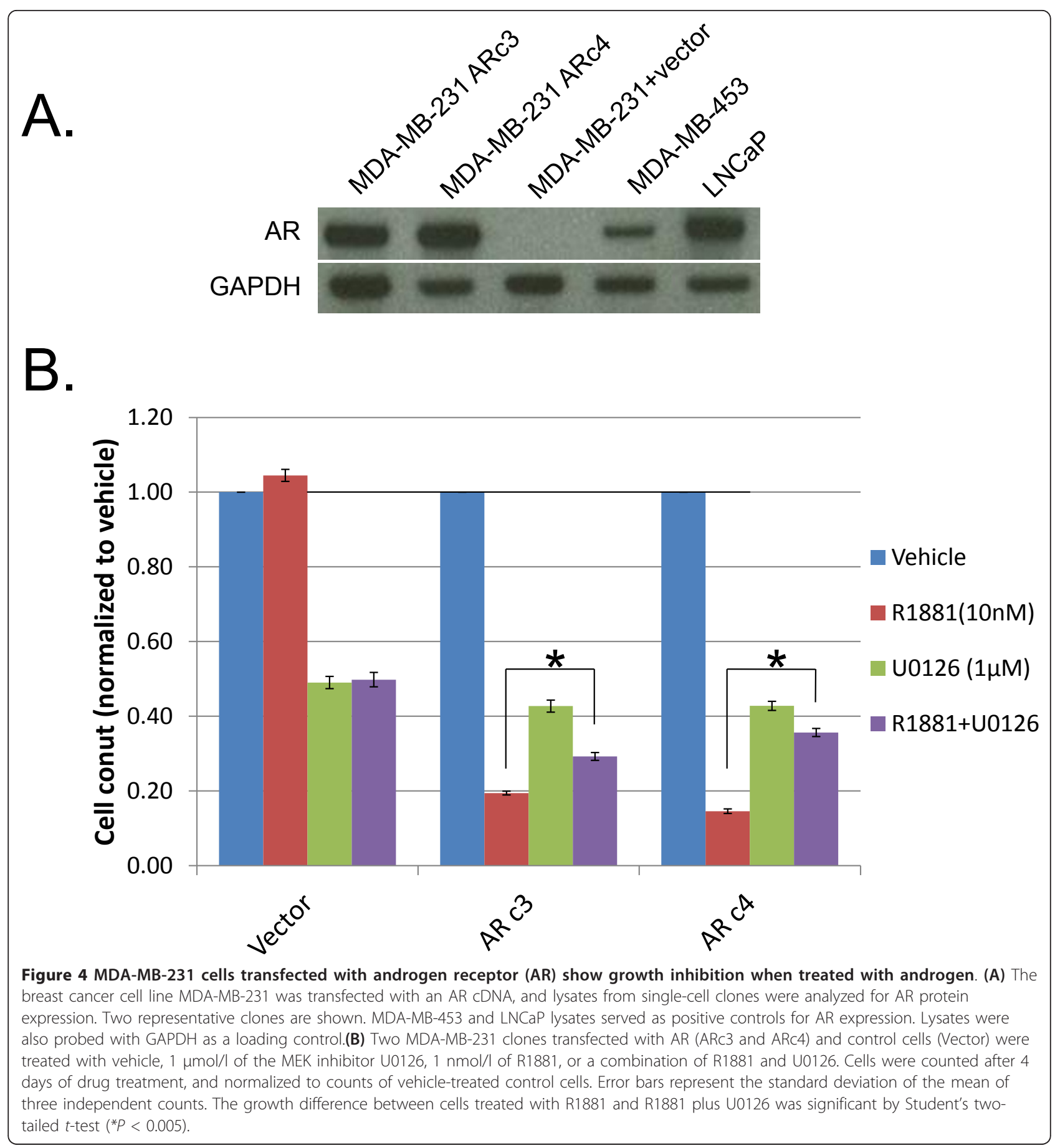

phase of the cell cycle (see Additional file 1 supplementary Figure 5) and that $p 21$ gene expression increased in ARIBE cells in response to R1881 (Figure 1C).

We further examined p21 expression in ARIBE cells treated with R1881, using western blotting. Within 24 hours of stimulation with AR ligand, ARIBE cells displayed upregulation of p21 protein expression (Figure 5A; see Additional file 1 supplementary Table 2). A similar result was seen in the MDA-MB-231 breast cancer cell lines that overexpress AR (Figure 5B; see Additional file 1 supplementary Table 2). It has been well described that cell cycle arrest mediated by $\mathrm{p} 21$ occurs via its induction by $\mathrm{p} 53$ [59]. However, in ARIBE cells induction of p21 appeared to be independent of p53 function, as the increased p21 levels induced by R1881 did not correlate with increased levels of p53 protein (data not shown). 


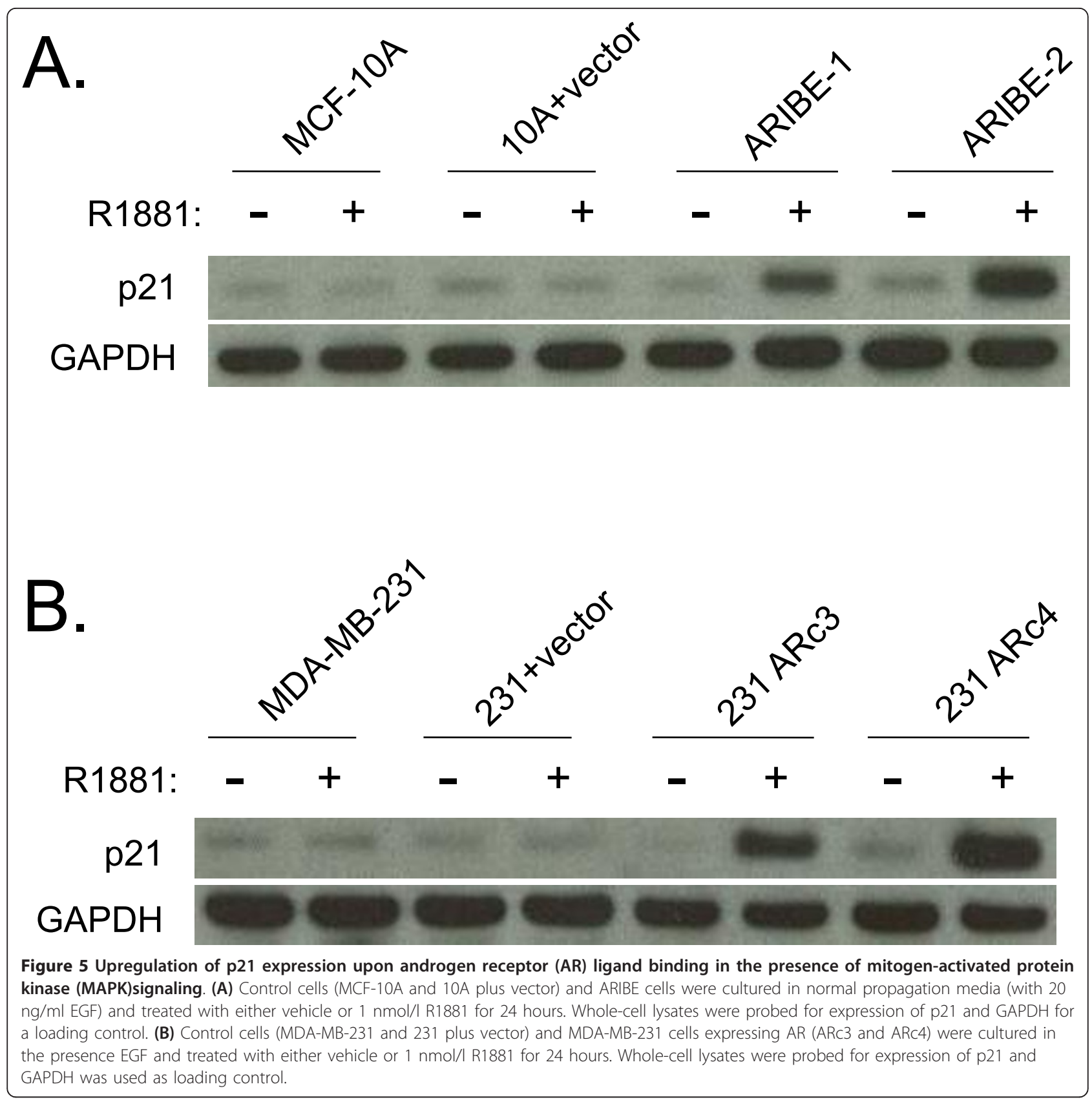

Additionally, we examined the expression of cyclin E and cyclin D1, two key regulators of cell cycle progression [60] After 48 hours of treatment with R1881 in the presence of EGF, cyclin E levels were not altered in ARIBE or control cell lines (data not shown), but levels of cyclin D1 were decreased by nearly $50 \%$ compared with control cell lines (see Additional file 1 supplementary Figure 7 and supplementary Table 2).

Taken together, these results suggest that dual exposure to EGF and R1881 leads to reduced cellular proliferation, as evidenced by increases in the CDK inhibitor p21 and decreases in cyclin D1 protein levels.
Although the striking increase in p21 protein levels upon R1881 exposure and the known role of p21 in mediating cell cycle arrest suggested that p21 might be a key mediator of AR-induced arrest, we sought to definitively confirm this using two complementary techniques: knock-down of $p 21$ gene expression via RNA interference (RNAi), and somatic cell gene knock-out, as described previously [61]. After transient transfection of siRNA into ARIBE cells a dramatic reduction in $\mathrm{p} 21$ protein was seen, compared with cells transfected with either a 'scrambled' control siRNA or with no siRNA (Figure 6A; see Additional file 1 supplementary Table 2). Transfected 


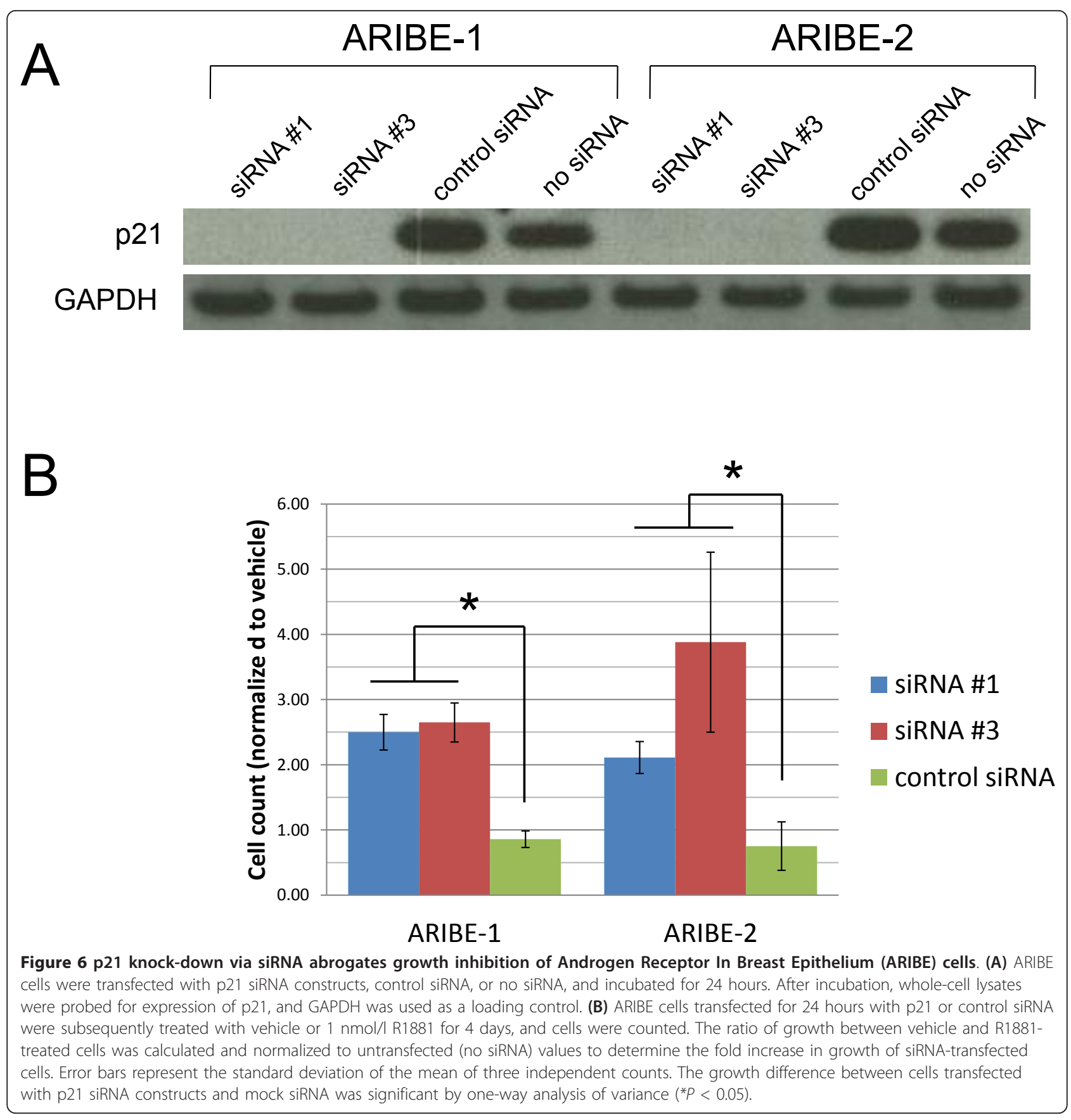

cells were then examined by proliferation assays. For control transfected cells, R1881 treatment produced significant growth inhibition in the presence of EGF as expected (Figure 6B). However, in transfected cells with p21 gene knock-down, the ability of R1881 to cause cell cycle arrest under full EGF conditions $(20 \mathrm{ng} / \mathrm{ml})$ was dramatically reduced compared with control cells $(P<$ 0.05). Because of the transient nature of siRNA and the longevity of the cell-proliferation assays in conditions with no EGF, effects of p21 knock-down on increased cell proliferation mediated by AR signaling could not be assessed.

Owing to this inability to assess the effect of $p 21$ gene knock-down under conditions of increased cell proliferation (that is, without EGF), and the fact that gene knock-down can produce non-specific toxicity and significant biologic differences compared with gene knockout [61], we next made use of our previously described MCF-10A somatic cell gene-targeted p21 null clones [36]. MCF-10A p $21^{-/-}$cells were stably transfected with 
the same AR cDNA used to create the ARIBE cell line. Clones with antibiotic resistance underwent a single-cell dilution process and multiple clones were isolated. Expression of AR was assayed by western blotting. Two representative clones (p21 $1^{-1-} \mathrm{AR}-1$ and $\left.\mathrm{p} 21^{-/-} \mathrm{AR}-4\right)$ had levels of AR expression comparable with those of the p21 wild-type ARIBE cells (Figure 7A; see Additional file 1 supplementary Table 2).

To determine if p21 knock-out recapitulated the RNAi experiments, ARIBE clones and $\mathrm{p} 21^{-1-}$ AR cells were treated with R1881 in the presence of EGF. As shown previously, R1881 inhibited the growth of ARIBE cells. However, in cells with no functional p21, the effect of R1881 was greatly attenuated, as $\mathrm{p} 21^{-1-} \mathrm{AR}-1$ and $\mathrm{p} 21^{-1-}$ AR-4 clones did not show significant growth inhibition when treated with this AR ligand compared with p21 wild-type ARIBE cells (Figure 7B), similar to our p21 siRNA experiments. Predictably, bicalutamide did not have any effect in p21 null cells (see Additional file 1 supplementary Figure 8A).

We then tested ARIBE p21 wild-type and AR-positive p21 null cells with R1881 under conditions with no

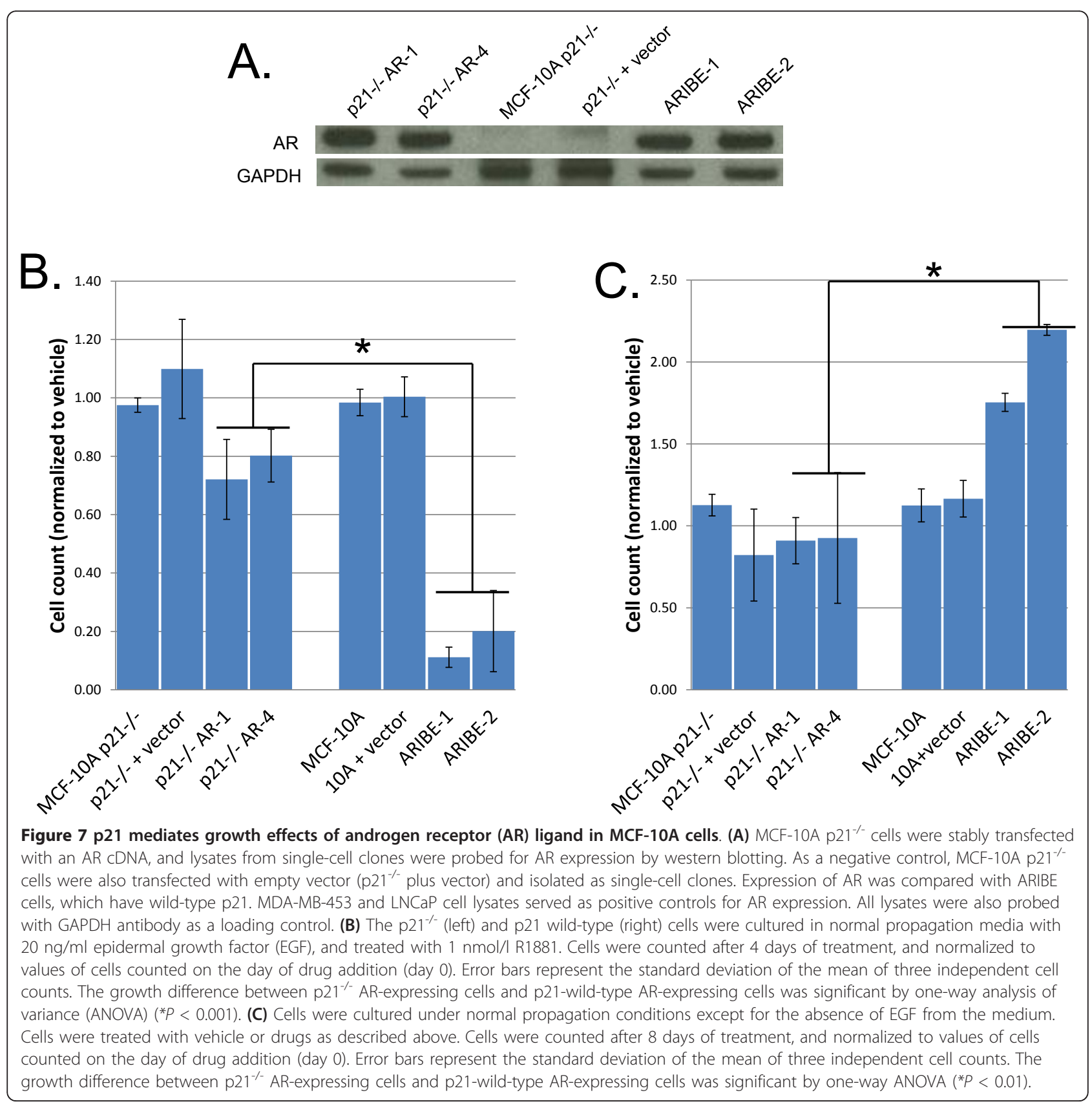


EGF. Somewhat unexpectedly, when cells were arrested via removal of EGF, p21 $1^{-/-}$AR cells did not show a growth-stimulated phenotype when treated with R1881, whereas the p21-wild-type ARIBE cells displayed the expected cell proliferation (Figure $7 \mathrm{C}$ ). Consistent with this finding, bicalutamide did not affect responses to R1881 in p21 null cells under culture conditions with no EGF (see Additional file 1 supplementary Figure $8 \mathrm{~B}$ ). This could reflect the known paradoxical role of p21 in initiating cell cycle progression in arrested cells [62]. An alternative, but not mutually exclusive possibility is that if p21 is necessary for AR-induced MAPK signaling, then lack of p21 might prevent activation of this pathway and therefore nullify the growth-promoting effects of AR signaling in the absence of EGF stimulation. Indeed, it has been previously reported that cyclin/CDK complexes can affect the MAPK cascade [63]. Therefore we hypothesized that without functional p21, ARexpressing cells would not show any increase in MAPK signaling, which could explain the lack of effect seen under both full EGF and no EGF culture conditions.

To formally address this hypothesis, we repeated the experiments performed on ARIBE cells and examined the levels of phosphorylated ERK in AR-expressing p21 null cells. We found that exposure to R1881 was no longer capable of increasing levels of phosphorylated ERK in p21 null cells regardless of AR expression or EGF growth conditions (Figure 8; see Additional file 1 supplementary Table 2).

Together, these data strongly suggest that in human breast epithelial cells, AR signaling requires p21 for MAPK activation, and that the level of MAPK activation via EGFR and AR signaling ultimately determines the response of cellular proliferation versus cell cycle arrest.

\section{Discussion}

Hormonal therapy is very successful for the treatment of breast cancer but remains limited to targeting the ER $\alpha$ pathway, as evidenced by the development of AIs and selective estrogen receptor modulators. However, drug resistance leading to recurrence of many of these ER $\alpha$ positive breast cancers necessitates continuing efforts to develop new therapies. This has recently spurred interest in $\mathrm{AR}$ as a potential breast cancer target for treating ER $\alpha$ positive hormone-resistant breast cancers. Moreover, 10\% to $20 \%$ of ER $\alpha /$ PR-negative breast cancers are AR-positive, which potentially opens the possibility of hormone therapies for these breast cancers as well. Furthermore, the history of success in targeting nuclear receptors for cancer treatment (breast cancer, prostate cancer, acute promyelocytic leukemia) gives confidence that targeting AR for breast cancer therapy could be of tremendous importance in treating this disease, and indeed clinical trials are currently underway to test this hypothesis $=[15]$. Historically, side-effect profiles have limited the use of targeted AR therapies for breast cancer [21], but a more vexing problem has been the inability to predict response in pre-clinical models. Because AR ligands can have opposing and paradoxical effects in various breast cancer cell lines expressing AR, applying AR-targeted therapies for breast cancer treatment has been challenging. In an effort to understand the effects of AR signaling in breast tissues with the goal of exploiting this knowledge for therapy, we generated cellular models of AR expression using the

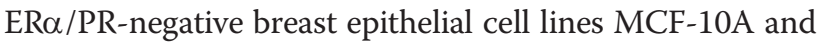
MDA-MB-231. The MCF-10A cell line in particular has many advantages over the use of cancerous cell lines because it is genetically stable, it does not contain mutations in genes commonly mutated in breast cancer, and

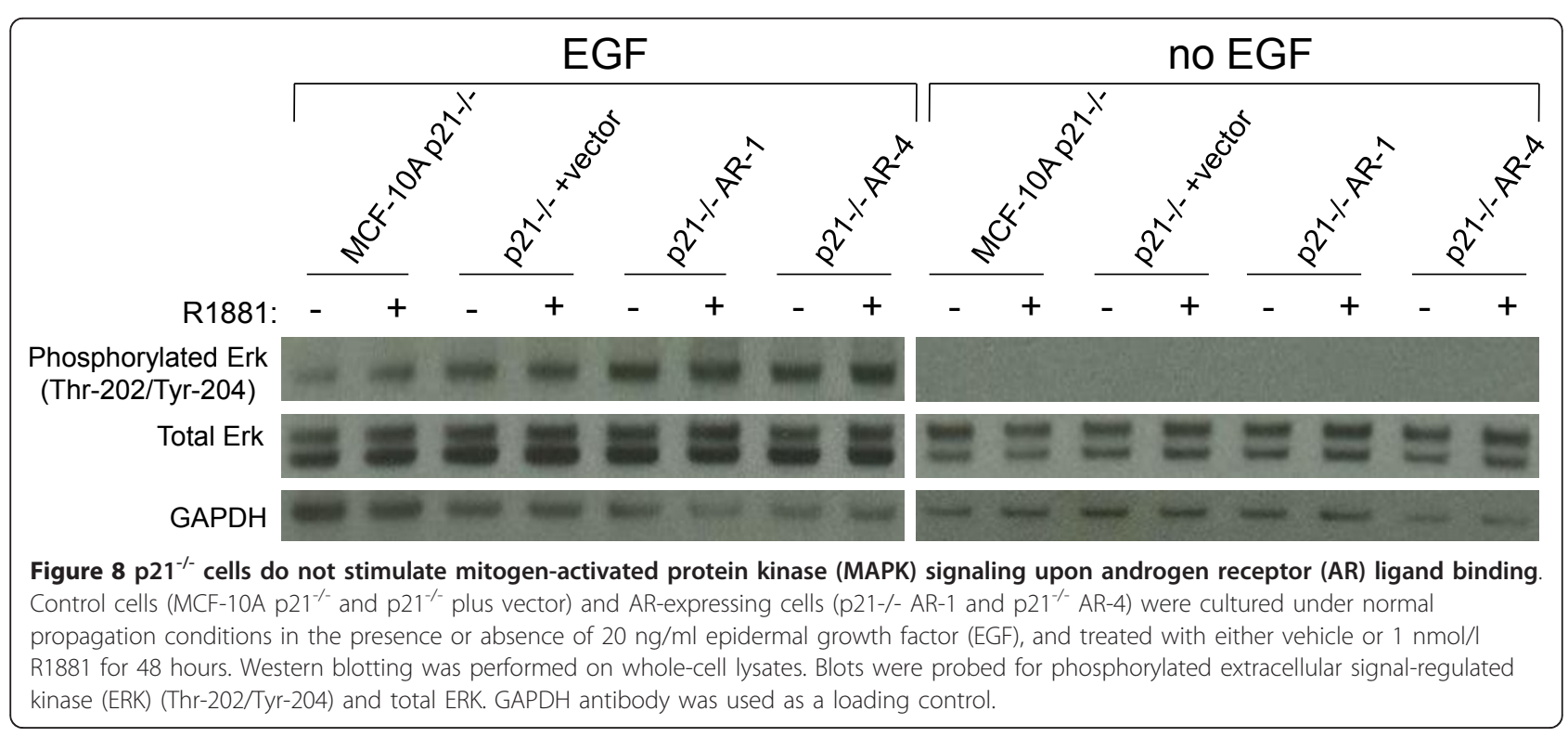


overexpression of nuclear hormone receptors results in physiologic signaling [34].

We characterized these cell lines using a variety of methods, and found that physiologic AR signaling is present in these cells and can induce increased transcription of genes via AREs and increased MAPK signaling. Importantly, our studies provide a number of mechanistic insights. First, R1881 bound to AR leads to increased MAPK signaling regardless of the growth phenotype. Second, AR signaling is dependent on the CDK inhibitor p21, as gene knock-down and knock-out largely abrogated all AR-mediated proliferation in these cell lines. Third, hyperactivation of the MAPK pathway by both EGFR and AR signaling leads to cell cycle arrest, whereas stimulation by either EGFR or AR alone results in cellular proliferation. Cellular arrest by EGFR and AR signaling may be similar to the phenomenon of oncogene-induced senescence, whereby activation of growth-promoting pathways beyond a critical threshold induces cell cycle arrest followed by senescence. Importantly, because our unique model is capable of displaying both growth phenotypes within the same cell line, it allows for the further study of genetic effectors that specifically mediate a growth stimulatory versus inhibitory response to AR signaling in human breast cells.

The fact that p21 is necessary for AR signaling leading to MAPK activation is consistent with previous reports that the p21 promoter contains an ARE [46]. Furthermore, our analyses showed that in both non-cancerous and cancerous human breast epithelial cells, AR ligand binding was associated with an increase in $p 21$ gene expression regardless of the growth phenotype. This may have important clinical considerations, as we have previously reported that loss of p21 expression is seen in up to $40 \%$ of human breast cancers [36]. It might therefore be possible for p21 to be used as a negative predictive marker of response in AR-positive breast cancers that are otherwise eligible for future AR-targeted therapies. In addition, our results open the possibility of using activating genetic alterations or mutations of the MAPK pathway as potential positive predictors of response to AR-directed drugs. Because we have previously shown that hyperactivation of the EGFR pathway mimics oncogenic PIK3CA mutations [64], our results would suggest that breast cancers with mutant PIK3CA and AR expression would have a favorable therapeutic response to AR ligand binding. By contrast, molecular apocrine tumors may benefit from dual MEK and AR inhibition as previously reported [18], and similar results may also apply to HER2-positive/AR-positive breast cancers. Further studies to test these hypotheses may allow for the selection of those patients with breast cancer who will have the highest likelihood of responding to AR-targeted therapies.

\section{Conclusions}

In this study, we constructed new models for AR signaling in human breast epithelial cells. We found that activation of the MAPK pathway by either EGFR or AR signaling leads to cellular proliferation, whereas simultaneous input by both EGFR and AR leads to further increases in MAPK activation and cellular arrest. These findings help elucidate past observations of disparate growth responses to AR ligand binding in various human breast cancer cell lines. Additionally, methods to quantify activation of the MAPK pathway on human tissues may allow for the development of predictive markers of AR signaling that leads to a growth proliferative versus inhibitory phenotype. Moreover, we found that p21 is essential for mediating AR signaling in human breast epithelial cells, regardless of the growth response to AR ligand. Thus, AR expression in conjunction with the presence or absence of p21 may also be useful for predicting sensitivity versus resistance to AR-directed therapies. Significantly, our system provides an ideal model for further study. The use of ARIBE cell lines will help reveal genes and pathways that are crucial for mediating these growth effects, and potentially identify additional predictors of response to AR ligands, thereby accelerating the development of drugs targeting AR for breast cancer therapy.

\section{Additional material}

Additional file 1: Supplementary Figures 1 to 8 , Tables 1 and 2.

Supplementary figures (eight) and tables (two).

\section{Abbreviations \\ AR: androgen receptor; ARIBE: Androgen Receptor In Breast Epithelium; DAPI: 4'-6-diamidino-2-phenylindole; DMEM: Dulbecco's modified Eagle's medium; DMSO: dimethyl sulfoxide; EGF: epidermal growth factor; EGFR: epidermal growth factor receptor; ERa: estrogen receptor-a; ERK: extracellular signal- regulated kinase; FCS: fetal calf serum; GAPDH: glyceraldehyde 3-phosphate dehydrogenase; MAPK: mitogen-activated protein kinase; PR: progesterone receptor; PVDF: polyvinylidine fluoride; QPCR: quantitative PCR; RNAi: RNA interference; SSC: saline sodium citrate; siRNA: small interfering RNA; TBP: TATA binding protein.}

\section{Acknowledgements}

Grant support was provided by an ASCO Foundation Young Investigator Award (MJH, DPC); the DOD Breast Cancer Research Program BC087658 (MJH), W81XWH-06-1-0325 (JP Gustin), BC083057 (MM); Susan G Komen for the Cure PDF0707944 (AMA, MJH), KG090199 (JL), BCTR0707684 (BHP); the Flight Attendant Medical Research Institute (FAMRI) (JL, HK); the $V$ Foundation ( $(L)$; the Maryland Cigarette Restitution Fund ( $L$ ); the Avon Foundation (JL, BHP); NIH CA088843 (JL, BHP); CA109274 (JP Garay is a recipient of a Research Supplement to Promote Diversity in Health-Related Research, BHP), GM007309 (GMW), CA009071 (DPC), and CA09071 (DJ). This research was supported in part by the Intramural Research Program of the $\mathrm{NIH}$, National Institute on Aging. None of these funding agencies had any role in study design, in the collection, analysis, and interpretation of data, in the writing of the manuscript, or in the decision to submit the manuscript for publication. 


\section{Author details}

${ }^{1}$ The Sidney Kimmel Comprehensive Cancer Center, The Johns Hopkins University School of Medicine, Baltimore, MD, USA. ${ }^{2}$ The Whiting School of Engineering, Department of Chemical and Biomolecular Engineering, The Johns Hopkins University, Baltimore, MD, USA. ${ }^{3}$ Laboratory of Molecular Biology and Immunology, National Institute on Aging, Baltimore MD, USA.

\section{Authors' contributions}

JP Garay, BK, AMA, MJH, DPC, DJ, AW, PJM, AM, AMD, PA, and BHP designed the experiments; JP Garay, JP Gustin, HK, YK, MM, GMW, CASB, AT, AM, GL and AS performed the experiments; JP Garay, BK, AMA, DPC, MJH, DJ, CASB, PA, AMA and BHP analyzed the data; and JP Garay and BHP wrote the paper. All authors read and approved the final manuscript.

\section{Competing interests}

B.H.P. has received previous research funding from GlaxoSmithKline (GSK) although none of the studies reported here were supported by GSK. B.H.P. is a consultant for GSK and is on the scientific advisory board for Horizon Discovery, LTD and is entitled to payments for these services. These arrangements are managed according to the Johns Hopkins University conflict of interest policy. All of the other authors declare that they have no competing interests.

Received: 26 June 2011 Revised: 27 September 2011

Accepted: 9 February 2012 Published: 9 February 2012

\section{References}

1. van de Velde CJ, Verma S, van Nes JG, Masterman C, Pritchard KI: Switching from tamoxifen to aromatase inhibitors for adjuvant endocrine therapy in postmenopausal patients with early breast cancer. Cancer Treat Rev 2009.

2. Cauley JA, Lucas FL, Kuller LH, Stone K, Browner W, Cummings SR: Elevated serum estradiol and testosterone concentrations are associated with a high risk for breast cancer. Study of Osteoporotic Fractures Research Group. Ann Intern Med 1999, 130:270-277.

3. Hankinson SE, Willett WC, Manson JE, Colditz GA, Hunter DJ, Spiegelman D, Barbieri RL, Speizer FE: Plasma sex steroid hormone levels and risk of breast cancer in postmenopausal women. J Natl Cancer Inst 1998, 90:1292-1299.

4. Dimitrakakis C, Bondy C: Androgens and the breast. Breast Cancer Res 2009, 11:212.

5. Lea OA, Kvinnsland $\mathrm{S}$, Thorsen T: Improved measurement of androgen receptors in human breast cancer. Cancer Res 1989, 49:7162-7167.

6. Moinfar F, Okcu M, Tsybrovskyy O, Regitnig P, Lax SF, Weybora W, Ratschek M, Tavassoli FA, Denk H: Androgen receptors frequently are expressed in breast carcinomas: potential relevance to new therapeutic strategies. Cancer 2003, 98:703-711.

7. Agoff SN, Swanson PE, Linden H, Hawes SE, Lawton TJ: Androgen receptor expression in estrogen receptor-negative breast cancer. Immunohistochemical, clinical, and prognostic associations. Am J Clin Pathol 2003, 120:725-731.

8. Park S, Koo J, Park HS, Kim JH, Choi SY, Lee JH, Park BW, Lee KS: Expression of androgen receptors in primary breast cancer. Ann Oncol 2010, 21:488-492.

9. Niemeier LA, Dabbs DJ, Beriwal S, Striebel JM, Bhargava R: Androgen receptor in breast cancer: expression in estrogen receptor-positive tumors and in estrogen receptor-negative tumors with apocrine differentiation. Mod Pathol 2010, 23:205-212.

10. Hu R, Dawood S, Holmes MD, Collins LC, Schnitt SJ, Cole K, Marotti JD, Hankinson SE, Colditz GA, Tamimi RM: Androgen receptor expression and breast cancer survival in postmenopausal women. Clin Cancer Res 2011, 17:1867-1874.

11. Peters AA, Buchanan G, Ricciardelli C, Bianco-Miotto T, Centenera MM, Harris JM, Jindal S, Segara D, Jia L, Moore NL, Henshall SM, Birrell SN, Coetzee GA, Sutherland RL, Butler LM, Tilley WD: Androgen receptor inhibits estrogen receptor-alpha activity and is prognostic in breast cancer. Cancer Res 2009, 69:6131-6140.

12. Castellano I, Allia E, Accortanzo V, Vandone AM, Chiusa L, Arisio R, Durando A, Donadio M, Bussolati G, Coates AS, Viale G, Sapino A: Androgen receptor expression is a significant prognostic factor in estrogen receptor positive breast cancers. Breast Cancer Res Treat 2010, 124:607-617.

13. Buchanan G, Birrell SN, Peters AA, Bianco-Miotto T, Ramsay K, Cops EJ, Yang M, Harris JM, Simila HA, Moore NL, Bentel JM, Ricciardelli C, Horsfall DJ, Butler LM, Tilley WD: Decreased androgen receptor levels and receptor function in breast cancer contribute to the failure of response to medroxyprogesterone acetate. Cancer Res 2005, 65:8487-8496.

14. Lonning PE: Additive endocrine therapy for advanced breast cancer back to the future. Acta Oncol 2009, 48:1092-1101.

15. Gucalp A, Traina TA: Triple-negative breast cancer: role of the androgen receptor. Cancer J 2010, 16:62-65.

16. Lehmann BD, Bauer JA, Chen $X$, Sanders ME, Chakravarthy AB, Shyr $Y$, Pietenpol JA: Identification of human triple-negative breast cancer subtypes and preclinical models for selection of targeted therapies. $J$ Clin Invest 2011, 121:2750-2767

17. Robinson JL, Macarthur S, Ross-Innes CS, Tilley WD, Neal DE, Mills IG, Carroll JS: Androgen receptor driven transcription in molecular apocrine breast cancer is mediated by FoxA1. Embo J 2011, 30:3019-3027.

18. Naderi A, Chia KM, Liu J: Synergy between inhibitors of androgen receptor and MEK has therapeutic implications in estrogen receptornegative breast cancer. Breast Cancer Res 2011, 13:R36.

19. Nahleh Z: Androgen receptor as a target for the treatment of hormone receptor-negative breast cancer: an unchartered territory. Future Oncol 2008, 4:15-21.

20. Ni M, Chen Y, Lim E, Wimberly H, Bailey ST, Imai Y, Rimm DL, Liu XS, Brown M: Targeting androgen receptor in estrogen receptor-negative breast cancer. Cancer Cell 2011, 20:119-131.

21. Kennedy BJ: Fluoxymesterone therapy in advanced breast cancer. $N$ Engl J Med 1958, 259:673-675

22. Birrell SN, Bentel JM, Hickey TE, Ricciardelli C, Weger MA, Horsfall DJ, Tilley WD: Androgens induce divergent proliferative responses in human breast cancer cell lines. J Steroid Biochem Mol Biol 1995, 52:459-467.

23. Yoon DS, Wersto RP, Zhou W, Chrest FJ, Garrett ES, Kwon TK, Gabrielson E: Variable levels of chromosomal instability and mitotic spindle checkpoint defects in breast cancer. Am J Pathol 2002, 161:391-397.

24. De Amicis F, Thirugnansampanthan J, Cui Y, Selever J, Beyer A, Parra I, Weigel NL, Herynk MH, Tsimelzon A, Lewis MT, Chamness GC, Hilsenbeck SG, Ando S, Fuqua SA: Androgen receptor overexpression induces tamoxifen resistance in human breast cancer cells. Breast Cancer Res Treat 2010, 121:1-11.

25. Isola JJ: Immunohistochemical demonstration of androgen receptor in breast cancer and its relationship to other prognostic factors. J Pathol 1993, 170:31-35.

26. Doane AS, Danso M, Lal P, Donaton M, Zhang L, Hudis C, Gerald WL: An estrogen receptor-negative breast cancer subset characterized by a hormonally regulated transcriptional program and response to androgen. Oncogene 2006, 25:3994-4008.

27. Kuenen-Boumeester V, Van der Kwast TH, van Putten WL, Claassen C, van Ooijen B, Henzen-Logmans SC: Immunohistochemical determination of androgen receptors in relation to oestrogen and progesterone receptors in female breast cancer. Int J Cancer 1992, 52:581-584.

28. Riva C, Dainese E, Caprara G, Rocca PC, Massarelli G, Tot T, Capella C, Eusebi V: Immunohistochemical study of androgen receptors in breast carcinoma. Evidence of their frequent expression in lobular carcinoma. Virchows Arch 2005, 447:695-700.

29. Panet-Raymond V, Gottlieb B, Beitel LK, Pinsky L, Trifiro MA: Interactions between androgen and estrogen receptors and the effects on their transactivational properties. Mol Cell Endocrinol 2000, 167:139-150.

30. Bentel JM, Birrell SN, Pickering MA, Holds DJ, Horsfall DJ, Tilley WD: Androgen receptor agonist activity of the synthetic progestin, medroxyprogesterone acetate, in human breast cancer cells. Mol Cell Endocrinol 1999, 154:11-20.

31. Bhattacharyya RS, Krishnan AV, Swami S, Feldman D: Fulvestrant (ICI $182,780)$ down-regulates androgen receptor expression and diminishes androgenic responses in LNCaP human prostate cancer cells. Mol Cancer Ther 2006, 5:1539-1549.

32. Wasielewski M, Elstrodt F, Klijn JG, Berns EM, Schutte M: Thirteen new p53 gene mutants identified among 41 human breast cancer cell lines. Breast Cancer Res Treat 2006, 99:97-101.

33. She QB, Chandarlapaty S, Ye Q, Lobo J, Haskell KM, Leander KR, DeFeoJones D, Huber HE, Rosen N: Breast tumor cells with PI3K mutation or 
HER2 amplification are selectively addicted to Akt signaling. PLOS ONE 2008, 3:e3065.

34. Abukhdeir AM, Blair BG, Brenner K, Karakas B, Konishi H, Lim J, Sahasranaman V, Huang Y, Keen J, Davidson N, Vitolo MI, Bachman KE, Park BH: Physiologic estrogen receptor alpha signaling in nontumorigenic human mammary epithelial cells. Breast Cancer Res Treat 2006, 99:23-33.

35. Soule HD, Maloney TM, Wolman SR, Peterson WD, Brenz R, McGrath CM, Russo J, Pauley RJ, Jones RF, Brooks SC: Isolation and characterization of a spontaneously immortalized human breast epithelial cell line, MCF-10. Cancer Res 1990, 50:6075-6086.

36. Bachman KE, Blair BG, Brenner K, Bardelli A, Arena S, Zhou S, Hicks J, De Marzo AM, Argani P, Park BH: p21(WAF1/CIP1) Mediates the Growth Response to TGF-beta in Human Epithelial Cells. Cancer Biol Ther 2004 3:221-225

37. Favata MF, Horiuchi KY, Manos EJ, Daulerio AJ, Stradley DA, Feeser WS, Van Dyk DE, Pitts WJ, Earl RA, Hobbs F, Copeland RA, Magolda RL, Scherle PA, Trzaskos JM: Identification of a novel inhibitor of mitogen-activated protein kinase kinase. J Biol Chem 1998, 273:18623-18632.

38. ImageJ. [http://rsb.info.nih.gov/ij/].

39. Gonzalez-Angulo AM, Stemke-Hale K, Palla SL, Carey M, Agarwal R, MericBerstam F, Traina TA, Hudis C, Hortobagyi GN, Gerald WL, Mills GB, Hennessy BT: Androgen receptor levels and association with PIK3CA mutations and prognosis in breast cancer. Clin Cancer Res 2009, 15:2472-2478.

40. Linja MJ, Savinainen KJ, Saramaki OR, Tammela TL, Vessella RL, Visakorpi T: Amplification and overexpression of androgen receptor gene in hormone-refractory prostate cancer. Cancer Res 2001, 61:3550-3555.

41. Albertson DG: Conflicting evidence on the frequency of ESR1 amplification in breast cancer. Nat Genet 2008, 40:821-822.

42. Liu W, Xie CC, Zhu Y, Li T, Sun J, Cheng Y, Ewing CM, Dalrymple S, Turner AR, Isaacs JT, Chang BL, Zheng SL, Isaacs WB, Xu J: Homozygous deletions and recurrent amplifications implicate new genes involved in prostate cancer. Neoplasia 2008, 10:897-907.

43. Magklara A, Grass L, Diamandis EP: Differential steroid hormone regulation of human glandular kallikrein (hK2) and prostate-specific antigen (PSA) in breast cancer cell lines. Breast Cancer Res Treat 2000, 59:263-270.

44. Vendola K, Zhou J, Wang J, Bondy CA: Androgens promote insulin-like growth factor-I and insulin-like growth factor-I receptor gene expression in the primate ovary. Hum Reprod 1999, 14:2328-2332.

45. Yanase T, Fan W: Modification of androgen receptor function by IGF-1 signaling implications in the mechanism of refractory prostate carcinoma. Vitam Horm 2009, 80:649-666.

46. Lu S, Liu M, Epner DE, Tsai SY, Tsai MJ: Androgen regulation of the cyclindependent kinase inhibitor p21 gene through an androgen response element in the proximal promoter. Mol Endocrinol 1999, 13:376-384.

47. Nelson PS, Clegg N, Arnold H, Ferguson C, Bonham M, White J, Hood L, Lin B: The program of androgen-responsive genes in neoplastic prostate epithelium. Proc Natl Acad Sci USA 2002, 99:11890-11895.

48. Bolton EC, So AY, Chaivorapol C, Haqq CM, Li H, Yamamoto KR: Cell- and gene-specific regulation of primary target genes by the androgen receptor. Genes Dev 2007, 21:2005-2017.

49. von Bueren $\mathrm{AO}, \mathrm{Ma} \mathrm{R}$, Schlumpf M, Lichtensteiger W: Salbutamol exhibits androgenic activity in vitro. Br J Sports Med 2007, 41:874-878, discussion 878

50. Blankvoort BM, de Groene EM, van Meeteren-Kreikamp AP, Witkamp RF, Rodenburg RJ, Aarts JM: Development of an androgen reporter gene assay (AR-LUX) utilizing a human cell line with an endogenously regulated androgen receptor. Anal Biochem 2001, 298:93-102.

51. Ma R, Cotton B, Lichtensteiger W, Schlumpf M: UV filters with antagonistic action at androgen receptors in the MDA-kb2 cell transcriptionalactivation assay. Toxicol Sci 2003, 74:43-50.

52. Chou JL, Fan Z, DeBlasio T, Koff A, Rosen N, Mendelsohn J: Constitutive overexpression of cyclin D1 in human breast epithelial cells does not prevent G1 arrest induced by deprivation of epidermal growth factor. Breast Cancer Res Treat 1999, 55:267-283.

53. Zhu X, Li H, Liu JP, Funder JW: Androgen stimulates mitogen-activated protein kinase in human breast cancer cells. Mol Cell Endocrinol 1999, 152:199-206.
54. Davidson NE, Gelmann EP, Lippman ME, Dickson RB: Epidermal growth factor receptor gene expression in estrogen receptor-positive and negative human breast cancer cell lines. Mol Endocrinol 1987, 1:216-223.

55. Fitzpatrick SL, LaChance MP, Schultz GS: Characterization of epidermal growth factor receptor and action on human breast cancer cells in culture. Cancer Res 1984, 44:3442-3447.

56. Ho-Kim MA, Tremblay RR, Dube JY: Binding of methyltrienolone to glucocorticoid receptors in rat muscle cytosol. Endocrinology 1981 109:1418-1423.

57. Sarkisian CJ, Keister BA, Stairs DB, Boxer RB, Moody SE, Chodosh LA: Dosedependent oncogene-induced senescence in vivo and its evasion during mammary tumorigenesis. Nat Cell Biol 2007, 9:493-505.

58. el-Deiry WS, Harper JW, O'Connor PM, Velculescu VE, Canman CE, Jackman J, Pietenpol JA, Burrell M, Hill DE, Wang Y, et al: WAF1/CIP1 is induced in p53-mediated G1 arrest and apoptosis. Cancer Res 1994, 54:1169-1174.

59. el-Deiry WS, Tokino T, Velculescu VE, Levy DB, Parsons R, Trent JM, Lin D, Mercer WE, Kinzler KW, Vogelstein B: WAF1, a potential mediator of p53 tumor suppression. Cell 1993, 75:817-825.

60. Sherr CJ, Roberts JM: Living with or without cyclins and cyclin-dependent kinases. Genes Dev 2004, 18:2699-2711.

61. Karakas B, Weeraratna AT, Abukhdeir AM, Konishi H, Gustin JP, Vitolo MI, Bachman KE, Park BH: p21 Gene knock Down Does Not Identify Genetic Effectors Seen with Gene Knock Out. Cancer Biol Ther 2007, 6:1025-1030.

62. Abukhdeir AM, Park BH: P21 and p27: roles in carcinogenesis and drug resistance. Expert Rev Mol Med 2008, 10:e19.

63. Strickfaden SC, Winters MJ, Ben-Ari G, Lamson RE, Tyers M, Pryciak PM: A mechanism for cell-cycle regulation of MAP kinase signaling in a yeast differentiation pathway. Cell 2007, 128:519-531.

64. Higgins MJ, Beaver JA, Wong HY, Gustin JP, Lauring JD, Garay JP, Konishi H, Mohseni M, Wang GM, Cidado J, Jelovac D, Cosgrove DP, Tamaki A, Abukhdeir AM, Park BH: PIK3CA mutations and EGFR overexpression predict for lithium sensitivity in human breast epithelial cells. Cancer Biol Ther 2011, 11:35-44.

\section{doi:10.1186/bcr3112}

Cite this article as: Garay et al.: The growth response to androgen receptor signaling in ER $\alpha$-negative human breast cells is dependent on p21 and mediated by MAPK activation. Breast Cancer Research 201214 R27.

\section{Submit your next manuscript to BioMed Central and take full advantage of:}

- Convenient online submission

- Thorough peer review

- No space constraints or color figure charges

- Immediate publication on acceptance

- Inclusion in PubMed, CAS, Scopus and Google Scholar

- Research which is freely available for redistribution

Submit your manuscript at www.biomedcentral.com/submit
C Biomed Central 